\title{
Is the WTO Truly Effective?
}

\section{Yutaka Kurihara}

Department of Economics, Aichi University, Nagoya, Japan.

Email: kurihara@vega.aichi-u.ac.jp

Received February $21^{\text {st }}, 2012$; revised March $12^{\text {th }}, 2012$; accepted March $22^{\text {nd }}, 2012$

\begin{abstract}
Whether or not the World Trade Organization (WTO) has promoted international trade is under dispute. This article uses a revised traditional gravity model to conduct empirical examination of this problem and found that WTO has recently promoted international trade and that the degree of increase is larger in developed countries than in developing ones. Moreover, regional trade agreements (RTA), currency unions, GDP, and distance are related to the increase of international trade along with the effects of WTO activities. On the other hand, the effect of distance on international trade has been decreasing. Improvements in information technology (IT) may have influenced this finding.
\end{abstract}

Keywords: Gravity Model; International Trade; IT; WTO

\section{Introduction}

The WTO provides a forum for the negotiation of agreements with the goal of reducing obstacles to international trade and ensuring a level playing field for all, thus contributing to economic growth and development. This organization was born out of negotiations, and all aspects of its work are the result of negotiations. The bulk of the WTO's current work comes from the 1986-1994 negotiations, namely the Uruguay Round, and the General Agreement on Tariffs and Trade (GATT). The WTO is currently host to negotiations under the Doha Development Agenda launched in 2001 (WTO's HP).

The GATT/WTO has played important roles in the promotion of international trade. However, the effects of the WTO on international trade remain in dispute in academic fields. [1] used date from [2] data and found positive WTO effects. [3] also found that the GATT/WTO has been effective in increasing international trade. However, [2], which has been cited often, drew data from 175 countries and found little evidence of the WTO's role in the promotion of its members' international trade.

[4] showed that economic freedom does not always have the expected impact on international trade. [5] indicated that the North American Free Trade Agreement (NAFTA) promoted exports. [6] showed that the RTA threatens the trading system and brings discriminatory practices. [7] found that the integration in the Euro area had a positive effect on economic growth. Other studies (e.g., [8-14]) examined the effect of RTA on bilateral trade. $[15,16]$ showed that the introduction of the U.S. dollar as the domestic currency would be beneficial to
APEC countries. [17] suggested that the replacement of their own currencies with another currency would promote international trade for the Pacific states. [18] showed strong evidence that supports RTAs and currency unions (CUs). [19] showed that the CU's trade effect is from $40 \%$ to about $100 \%$. [20-22] also examined the impact of CU on international trade.

Disputes continue between developed countries and developing countries about the role of the GATT/WTO. [23] found large WTO trade effects for industrializing economies. [24] showed that the WTO increases trade among developing economies. [25,26] showed that protections in developing economies may lead to economic stagnation. This article takes these facts into account for empirical study.

The gravity model of international trade, which has been used often, states that bilateral trade flows are based on the economic sizes (i.e., GDP) and distances between two units or countries. This model is often extended by including variables to explain language relationships, contiguity, colonial history, exchange rate regimes, and other variables [2,3,27]. However, [6,28,29] indicated that estimation using the gravity model suffers from omitted variable bias. Another problem is so-called zero trade observations. This implies that zeros (the data on trade volume) are not randomly dropped, which causes bias. This article considers these points.

This article is organized as follows. The next section shows the empirical methods and the data used here. Section 3 demonstrates the results and examines them. Finally this paper ends with a brief summary. 


\section{Theoretical Analysis and Empirical Method}

In international trade literature, the gravity model has become a popular method to estimate trade flows. This model has been repeatedly employed in academic study. In its simple form, this model for bilateral trade states that imports (or exports) of country $i$ from country $j$ $\left(\mathrm{TRADE}_{\mathrm{ij}}\right)$ are proportional to the product of the two countries' GDPs $\left(\mathrm{GDP}_{\mathrm{i}}\right.$ and $\mathrm{GDP}_{\mathrm{j}}$ ) and inversely proportional to their geographical distance (dist):

$$
\operatorname{TRADE}_{\mathrm{ij}}=\alpha_{0} \frac{\mathrm{GDP}_{\mathrm{i}}^{\alpha_{1}} \mathrm{GDP}_{\mathrm{i}}^{\alpha_{2}}}{\operatorname{dist}^{\alpha_{3}}}
$$

A typical, empirically consistent specification without bilateral fixed effects is given as follows:

$$
\begin{aligned}
& \ln \left(\operatorname{TRADE}_{\mathrm{ijt}}\right)=\alpha_{0}+\alpha_{1} \mathrm{WTO}(\text { both })_{\mathrm{ijt}} \\
& \quad+\alpha_{2} \mathrm{WTO}(\text { one })_{\mathrm{ijt}}+\alpha_{3} \mathrm{RTA}_{\mathrm{ijt}}+\alpha_{4} \mathrm{CU}_{\mathrm{ijt}} \\
& \quad+\alpha_{5} \ln \left(\mathrm{GDP}_{\mathrm{i}} \mathrm{GDP}_{\mathrm{j}}\right)_{\mathrm{t}}+\alpha_{6} \mathrm{dist}_{\mathrm{ijt}}+\mu_{\mathrm{it}}+\mu_{\mathrm{jt}}+\varepsilon_{\mathrm{ij}}+\varepsilon_{\mathrm{ijt}}
\end{aligned}
$$

where $\mathrm{i}$ and $\mathrm{j}$ are countries (units) and TRADE means the value of bilateral trade. As one of the purposes of this article is to analyze whether or not the WTO has been effective, two dependent variables are included. WTO (both) is a dummy variable that takes the value one if both $\mathrm{i}$ and $\mathrm{j}$ are members at time $\mathrm{t}$ and zero otherwise; WTO (one) is a dummy variable that takes the value one if either $\mathrm{i}$ or $\mathrm{j}$ is considered to be a WTO member at time $t$ and zero otherwise as [19]. RTA and CU are dummy variables that take the value of one if $i$ and $j$ belong to regional trade agreement and the currency union at time $t$ and zero otherwise. dist is the distance between the capitals of coutries $\mathrm{i}$ and $\mathrm{j}$. GDP is the product of their real GDP. According to $[6,19,23], \mu_{\mathrm{it}}$ and $\mu_{\mathrm{jt}}$ are the countryby-time dummies. They control for country-specific unobservables that vary over time but not across trading partners, as well as GDP per capita, area and the multilateral resistance terms as explained in [23]. Other factors that affect international trade can be included with these $\mu_{\mathrm{it}}$ and $\mu_{\mathrm{jt}}$; variables. $\varepsilon_{\mathrm{ij}}+\varepsilon_{\mathrm{ijt}}$ are bilateral time-varying and time-invariant unobservables.

Finally, to include the zero trade observations, the dependent variable is considered to be in $\ln \left(\mathrm{TRADE}_{\mathrm{ijt}}+1\right)$ as in [3]. It is sometimes noted that the coefficient estimates from log-linear regressions are inconsistent when a large number of zero trade observations are present in the sample for empirical analysis.

The data are from Direction of Trade Statistics (IMF; for the TRADE data), WTO (for the data on WTO membership and RTA), Annual Report on Exchange Arrangements and Exchange Restrictions (IMF; for the data of $\mathrm{CU}$ ), International Financial Statistics (IMF; for the data on real GDP), and Infoplease (for distance data) from
2000 to 2010 at 5-year intervals (2000, 2005 and 2010). Non-OECD counties are available data countries for each sample as possible as I can. If any data were lacking, the country is omitted for that time. Non-OECD includes 80 countries.

\section{Estimated Results}

Table 1 reports the results of Equation (1). Both cases, the country-by-time dummies and non-country-by-time dummies, are estimated.

The use of either definition finds country-pairs with one or two WTO members to engage in significantly greater bilateral trade, relative to country-pairs that have no WTO members. Membership in the WTO can be supported for the promotion of international trade. Countrypairs in which both are WTO members engage in more bilateral trade using either definition of membership. The difference between OECD and non-OECD exists in the promotion of international trade. WTO promotes international trade more in OECD countries than in non-OECD countries; however, the WTO also promotes trade in nonOECD countries.

The difference between RTA and WTO is unclear; however, the RTA promotes international trade, and the effect on trade is larger than that for the WTO in general.

\begin{tabular}{|c|c|c|c|c|}
\hline & \multicolumn{2}{|c|}{$\begin{array}{l}\text { Country-by-Time } \\
\text { Dummies Excluded }\end{array}$} & \multicolumn{2}{|c|}{$\begin{array}{l}\text { Country-by-Time } \\
\text { Dummies Included }\end{array}$} \\
\hline & OECD & Non-OECD & OECD & Non-OECD \\
\hline & (1) & (2) & (3) & (4) \\
\hline WTO (both) & $\begin{array}{l}2.11^{* * *} \\
(5.45)\end{array}$ & $\begin{array}{l}1.95^{* * *} \\
(5.32)\end{array}$ & $\begin{array}{l}1.14^{* *} \\
(2.59)\end{array}$ & $\begin{array}{l}0.92^{* *} \\
(2.53)\end{array}$ \\
\hline WTO (one) & $\begin{array}{l}0.97^{* *} \\
(2.34)\end{array}$ & $\begin{array}{l}1.69^{* *} \\
(2.44)\end{array}$ & $\begin{array}{c}0.46^{*} \\
(1.89)\end{array}$ & $\begin{array}{c}0.72 \\
(1.40)\end{array}$ \\
\hline RTA & $\begin{array}{l}1.30^{* * *} \\
(3.98)\end{array}$ & $\begin{array}{l}1.62^{* * *} \\
(4.02)\end{array}$ & $\begin{array}{c}1.13^{*} \\
(1.82)\end{array}$ & $\begin{array}{l}1.20^{*} \\
(1.90)\end{array}$ \\
\hline $\mathrm{CU}$ & $\begin{array}{l}1.47^{* *} \\
(1.92)\end{array}$ & $\begin{array}{l}1.63^{* * *} \\
(2.99)\end{array}$ & $\begin{array}{c}1.02 \\
(1.21)\end{array}$ & $\begin{array}{l}1.17^{* *} \\
(2.32)\end{array}$ \\
\hline Real GDP & $\begin{array}{l}0.45^{* * *} \\
(6.13)\end{array}$ & $\begin{array}{l}0.49^{* * *} \\
(6.77)\end{array}$ & $\begin{array}{l}0.25^{* *} \\
(2.37)\end{array}$ & $\begin{array}{l}0.29^{* *} \\
(2.40)\end{array}$ \\
\hline Distance & $\begin{array}{l}-2.11^{* * *} \\
(-4.00)\end{array}$ & $\begin{array}{l}-3.03^{* * *} \\
(-4.28)\end{array}$ & $\begin{array}{l}-1.05^{*} \\
(-1.75)\end{array}$ & $\begin{array}{l}-1.51^{* *} \\
(-2.28)\end{array}$ \\
\hline F-value & 823.45 & 859.98 & 356.47 & 321.78 \\
\hline D.W. & 1.87 & 1.90 & 0.97 & 0.88 \\
\hline Adj. $R^{2}$ & 0.65 & 0.71 & 0.44 & 0.41 \\
\hline
\end{tabular}
The results mean that the RTA promotes international

Table 1. Estimated results for the gravity model of international trade. at $5 \%$; and ${ }^{*}$ at $10 \%$ level. 
trade $[14,16]$, and there is a possibility that the RTA conflicts with the WTO and promotes blocks of countries on the other hand. In the past, trading blocks have decreased international trade. It is interesting to note that the RTA promotes international trade in developing countries.

$\mathrm{CU}$ also has a positive influence on international trade. Stable exchange rates or stable currency values seem to be an important factor in the promotion of international trade. However, whether the difference exists between developed countries and developing ones is not clear. The increase of real GDP promotes international trade as expected. Increasing distances between countries (units) negatively impacts international trade, as many studies have suggested. For the distance between countries, Table 2 shows some interesting points (explained later).

It is quite difficult to judge the effect of country-bytime dummies on international trade. Some variables are not significant if these dummies are included in the equation. As explained in the previous section, these dummies can control for country-specific unobservables that vary over time but not across trading partners as well as GDP per capita, area and multilateral resistance terms. This method seems to be one of the effective ones; however, there is some possibility that important variable(s) is(are) omitted. However, the results are similar whether or not these dummies are included.

Next, Table 2 reports the estimation in Table 1, which is divided at the 5-year interval points (2000, 2005 and 2010). Only the estimations that omit country-by-time dummies are shown.

The results are not very clear; however, there are some interesting and important findings. In general, the effects of the WTO on international trade have been decreasing; on the other hand, the effects of the RTA have been increasing. The conclusion of the Uruguay Round (19861993) and the start of the WTO partially remedied the situation of the developing countries that wanted to participate in the WTO. However, these countries were then required to engage in serious trade liberalization.

The effect of distance has been decreasing. In the case of 2010, the variable is not significant [16]. The coefficient of OECD countries is positive (not significant). As noted in [30] and [31], one reason is that trade costs have declined sharply since the 1980s. Alternatively, improvements in IT may have contributed greatly. IT promotes international trade while decreasing costs and time.

\section{Conclusions}

This study found that the WTO has increased trade. However, the degree has been decreasing or not as large recently. The role of the RTA seems to be increasing. The distinction in the roles of the WTO and the RTA are important to increase international trade and to obtain sound economic growth. There will be conflict between the organizations in some cases. Also, the increase is larger in developed countries than in developing ones. Currency unions promote international trade. Real GDP,

Table 2. Estimated results for the gravity model of international trade.

\begin{tabular}{|c|c|c|c|c|c|c|}
\hline & \multicolumn{2}{|c|}{2000} & \multicolumn{2}{|c|}{2005} & \multicolumn{2}{|c|}{2010} \\
\hline & OECD & Non-OECD & OECD & Non-OECD & OECD & Non-OECD \\
\hline & (5) & (6) & (7) & (8) & (9) & (10) \\
\hline WTO (both) & $\begin{array}{l}2.21^{* * *} \\
(5.50)\end{array}$ & $\begin{array}{l}1.97^{* * *} \\
(5.28)\end{array}$ & $\begin{array}{l}2.09^{* * *} \\
(5.29)\end{array}$ & $\begin{array}{l}1.93^{* * *} \\
(5.22)\end{array}$ & $\begin{array}{l}1.99^{* * *} \\
(5.05)\end{array}$ & $\begin{array}{l}1.92^{* * *} \\
(5.16)\end{array}$ \\
\hline WTO (one) & $\begin{array}{l}1.10^{* * *} \\
(4.04)\end{array}$ & $\begin{array}{l}1.79^{* *} \\
(2.27)\end{array}$ & $\begin{array}{l}0.96^{* *} \\
(2.30)\end{array}$ & $\begin{array}{l}1.64^{* *} \\
(2.41)\end{array}$ & $\begin{array}{l}0.90^{* *} \\
(2.39)\end{array}$ & $\begin{array}{l}1.67^{* *} \\
(2.44)\end{array}$ \\
\hline RTA & $\begin{array}{c}1.21^{*} \\
(3.03)\end{array}$ & $\begin{array}{c}1.01^{*} \\
(1.92)\end{array}$ & $\begin{array}{l}1.25^{* *} \\
(2.60)\end{array}$ & $\begin{array}{l}1.56^{* * *} \\
(3.80)\end{array}$ & $\begin{array}{l}1.48^{* * *} \\
(4.01)\end{array}$ & $\begin{array}{l}1.99^{* * *} \\
(4.43)\end{array}$ \\
\hline $\mathrm{CU}$ & $\begin{array}{l}1.46^{* *} \\
(2.22)\end{array}$ & $\begin{array}{c}1.21^{*} \\
(1.86)\end{array}$ & $\begin{array}{l}1.98^{* * *} \\
(3.31)\end{array}$ & $\begin{array}{l}1.98^{* * *} \\
(3.71)\end{array}$ & $\begin{array}{c}0.98^{*} \\
(1.80)\end{array}$ & $\begin{array}{c}0.76 \\
(1.28)\end{array}$ \\
\hline Real GDP & $\begin{array}{l}0.45^{* * *} \\
(6.80)\end{array}$ & $\begin{array}{l}0.55^{* * *} \\
(6.34)\end{array}$ & $\begin{array}{l}0.41^{* * *} \\
(6.05)\end{array}$ & $\begin{array}{l}0.47^{* * *} \\
(6.68)\end{array}$ & $\begin{array}{l}0.40^{* * *} \\
(5.59)\end{array}$ & $\begin{array}{l}0.44^{* * *} \\
(5.37)\end{array}$ \\
\hline Distance & $\begin{array}{c}-2.48^{* * *} \\
(-4.84)\end{array}$ & $\begin{array}{c}-3.90^{* * *} \\
(-5.66)\end{array}$ & $\begin{array}{c}-2.01^{* * *} \\
(-3.66)\end{array}$ & $\begin{array}{l}-3.02^{* *} \\
(-4.61)\end{array}$ & $\begin{array}{c}0.33 \\
(0.27)\end{array}$ & $\begin{array}{l}-0.27^{*} \\
(-1.82)\end{array}$ \\
\hline F-value & 798.55 & 800.62 & 810.33 & 814.72 & 329.21 & 768.93 \\
\hline D.W. & 1.79 & 1.83 & 1.84 & 1.86 & 0.99 & 1.58 \\
\hline Adj. $R^{2}$ & 0.60 & 0.65 & 0.64 & 0.70 & 0.45 & 0.66 \\
\hline
\end{tabular}

Note: Numbers in parentheses are t statistics. ${ }^{* * *}$ denotes significant at $1 \% ;{ }^{* *}$ at $5 \%$; and ${ }^{*}$ at $10 \%$ level. 
along with the WTO, and distance are related to increases in international trade. On the other hand, the effect of distance on international trade has been decreasing. Improvements in IT may have influenced this trend.

\section{Acknowledgements}

This study is supported by Japanese KAKEN (Ministry of Education, Culture, Sports, Science \& Technology).

\section{REFERENCES}

[1] M. Tomz, J. L. Goldstein and D. Rivers, "Do We Know That the WTO Increase Trade? Comment," American Economic Review, Vol. 97, No. 5, 2007, pp. 2005-2018. doi:10.1257/aer.97.5.2005

[2] A. K. Rose, "Do We Really Know that the WTO Increase Trade," American Economics Review, Vol. 97, No. 5, 2007, pp. 2019-2025. doi:10.1257/aer.97.5.2019

[3] X. Liu, "GATT/WTO Promotes Trade Strongly: Sample Selection and Model Specification," Review of International Economics, Vol. 17, No. 3, 2009, pp. 428-446. doi:10.1111/j.1467-9396.2009.00816.x

[4] B. Christopher, "A Re-Examination of the Relation between Democracy and International Trade," The Journal of International Trade \& Economic Development, Vol. 20, No. 5, 2011, pp. 585-600.

[5] B. J. Frickel, V. V. Kotcherlakota, F. A. Tekorang and B. R. Elder, "The Effect of NAFTA on Trade and Investment between Member Countries," International Business and Economics Research Journal, Vol. 10, No. 6, 2011, pp. $1-8$.

[6] C. K. Lee, "WTO Negotiations between Democracy and Developed Countries: An Evolutionary Game Theory Approach," International Journal of Management, Vol. 28, No. 3, 2011, pp. 867-879.

[7] I. Siedschlag and G. Tondl, "Regional Output Growth Synchronisation with the Euro Area," Empirica, Vol. 38, No. 2, 2011, pp. 203-211. doi:10.1007/s10663-010-9130-7

[8] S. Coulibaly, "Evaluating the Trade Effect of Developing Regional Trade Agreements: A Semi-Parametric Approach," Journal of Economic Integration, Vol. 24, No. 4, 2009, pp. 709-743.

[9] J. Korinek and M. Melatos, "Trade Impacts of Selected Regional Trade Agreements in Agriculture," OECD Trade Policy Working Paper, No. 87, 2009, p. 59.

[10] I. Park, "Regional Trade Agreements in East Asia: Will They Be Sustainable?" Asian Economic Journal, Vol. 23, No. 2, 2009, pp. 169-194. doi:10.1111/j.1467-8381.2009.02008.x

[11] Y. Kurihara, "The Impact of Regional Trade Agreements on International Trade," Modern Economy, Vol. 2, No. 5, 2011, pp. 846-849. doi:10.4236/me.2011.25094

[12] A. Vamvakidis, "Regional Trade Agreement or Broad Liberalization: Which Path Leads to Faster Growth?" IMF Economic Review, Vol. 46, No. 1, 1999, pp. 42-52.

[13] J. Varzary, "The Failure of Regional and Multinational
Trade Agreements," The Business Review, Vol. 17, No.1, 2011, pp. 235-240.

[14] X. P. Liu, "Testing Conflicting Political Economy Theories: Full-Fledged Partial-Scope Regional Trade Agreements," Southern Economic Journal, Vol. 77, No. 1, 2010, pp. 78-103. doi:10.4284/sej.2010.77.1.78

[15] V. Vicard, "On Trade Creation and Regional Trade Agreements: Does Depth Matter?" Review of World Economics, Vol. 145, No. 2, 2009, pp. 167-187. doi:10.1007/s10290-009-0010-9

[16] Y. Kurihara, "APEC: International Trade and Economic Growth," Pacific Economic Review, Vol. 10, No. 2, 2003, pp. 27-42.

[17] S. Freitag, "Adopting External Currencies for Trade Growth in the Pacific," Asian-Pacific Economic Literature, Vol. 25, No. 1, 2011, pp. 103-120. doi:10.1111/j.1467-8411.2011.01273.x

[18] J. Roy, "On the Robustness of the Trade-Inducing Effects of Trade Agreements and Currency Unions," Appalachian State University Working Papers, Vol. 10, No. 9, 2010, pp. 1-39.

[19] J. Roy, "Is the WTO Mystery Really Solved?" Economics Letters, Vol. 113, No. 2, 2011, pp. 127-130. doi:10.1016/j.econlet.2011.06.010

[20] R. A. Frankel and A. Rose, "The Endogeneity of the Optimum Currency Area Criteria," The Economic Journal, Vol. 108, No. 449, 1998, pp. 1009-1025. doi:10.1111/1468-0297.00327

[21] H. Katayama and M. Melatos, "The Nonlinear Impact of Currency Unions on Bilateral Trade," Economics Letters, Vol. 112, No. 1, 2011, pp. 94-96. doi:10.1016/j.econlet.2011.03.022

[22] P. Krugman, "Lessons of Massachusetts for EMU," In: F. Glavazzi and F. Torres, Eds., The Transition to Economic and Monetary Union in Europe, Cambridge University Press, New York, 2001, pp. 241-261.

[23] A. Subramanian and S. Wei, "The WTO Promotes Trade, Strongly but Unevenly," Journal of International Economics, Vol. 72, No. 1, 2007, pp. 151-175. doi:10.1016/j.jinteco.2006.07.007

[24] T. S. Eicher and J. Henn, "In Search of WTO Trade Effects: Preferential Trade Agreements Promote Trade Strongly But Unevenly," Journal of International Economics, Vol. 83, No. 2, 2011, pp. 137-153. doi:10.1016/j.jinteco.2010.12.002

[25] Y. Lee, "Reconciling RTAs with the WTO Multinational Trading System: Case for a New Sunset Requirement on RTAs and Development Facilitation," Journal of World Trade, Vol. 45, No. 3, 2011, pp. 629-651.

[26] F. Tesón, "Why Free Trade Is Required by Justice," Social Philosophy and Policy, Vol. 29, No. 1, 2012, pp. 126-153. doi:10.1017/S0265052511000112

[27] M. Debasri and S. Pozo, "Exchange-Rate Volatility and Trade: A Semiparametric Approach?" Applied Economics, Vol. 43, No. 3, 2011, pp. 1617-1620. doi: $10.1080 / 00036840802600327$

[28] J. E. Anderson and E. van Wincoop, "Gravity with Gravitas: A Solution to the Border Puzzle," American Econo- 
mic Review, Vol. 93, No. 1, 2003, pp. 170-192. doi: $10.1257 / 000282803321455214$

[29] A. Fragikos and V. C. Nikos, "US Patents Abroad: Does Gravity Matter?" Journal of Technology Transfer, Vol. 36, No. 4, 2011, pp. 404-416.

[30] M. Kukenova and J. Monteiro, "Does Lax Environment
Regulation Attract FDI When Accounting for 'ThirdCountry' Effects?” MPRA Paper, No. 11321, 2008.

[31] D. H. Brooks and F. Benno, "Asia's Melting Trade Costs," The World Economy, Vol. 34, No. 7, 2011, pp. 1138-1150. doi:10.1111/j.1467-9701.2011.01369.x 